\title{
AN ANALYSIS OF INDEPENDENT CHARACTER OF PRIMARY SCHOOL STUDENTS IN LEARNING FROM HOME DURING THE COVID-19 PANDEMIC (A Case Study at SD Muhammadiyah 8 Surabaya)
}

\author{
Umar Haiq $^{{ }^{*}}$, Badruli Martati ${ }^{2}$, Fajar Setiawan ${ }^{3}$ \\ 1, 2, 3 Muhammadiyah University of Surabaya, East Java, Indonesia \\ Corresponding*Hai_q2012@ymail.co; badrulimartati@fkip.um-surabaya.ac.id; \\ fajarsetiawan@fkip.um-surabaya.ac.id
}

DOI: https://doi.org/10.21107/Widyagogik/v8i1.8798

Received October 8, 2020; Revised October 12, 2020; Accepted October 31, 2020

\begin{abstract}
This research aims to determine the process of the development of the independent character of elementary school students in learning from home during the Covid-19 pandemic at SD Muhammadiyah 8 Surabaya in grades 4, 5, and 6 by referring to the achievement of indicators of independent character values and the obstacles that arise in their achievement. By using a qualitative approach, the discussion will be presented in a descriptive explanation. The research subjects are 99 upper-class student respondents $(4,5$, and 6) at SD Muhammadiyah 8 Surabaya. The research is carried out only by taking data on March, April, and May 2020 as the research scope. In this research, data are collected giving online questionnaire observation techniques to students, accompanied by parents, and having direct interviews with class teachers and subject teachers. The discussion in this research shows that the level of development of the independent character of students has been built with an average of being in the category of culture and development even though there are still obstacles because they require assistance, either directly or indirectly from parents and teachers.
\end{abstract}

Keywords: Character, Independence, Covid-19 Pandemic 
56 An Analysis of Independent Character of Primary School Students in Learning From Home During The Covid-19 Pandemic (A Case Study at SD Muhammadiyah 8 Surabaya)

Umar Haiq, Badruli Martati, Fajar Setiawan

\section{Introduction}

The cultivation of character education can be integrated into the learning process both classically and individually. Both outside the classroom and in the classroom, both offline and online (online). Judging from the current conditions and referring to the Minister of Education and Culture circular number 4 of 2020 point 2, regarding the implementation of educational policies in the emergency period of the spread of the coronavirus disease (Covid-19) the learning process from home is carried out with the following conditions: "Learning from home (BDR)) through online or distance learning, it is carried out by providing meaningful learning experiences for students, in this case, students of SD Muhammadiyah 8 Surabaya in grades 4, 5, and 6, without being burdened by the target of completing all curriculum achievements in grade promotion and graduation; learning from home focuses on life skills education, including about the Covid-19 pandemic; learning activities and assignments from home among students, in this case, students of SD Muhammadiyah 8 Surabaya grades 4, 5 and 6 can vary, according to their respective interests and conditions, and also consider gaps in access/learning facilities at home; The educators give qualitative and useful feedback on portfolios or products of home learning activities, without having to score/score quantitatively. Independence will be an important milestone for solutions to achieve the goals of education in the current pandemic situation, children will be able to gain a more realistic learning experience from the environment to be applied in life skills.

Independence has the basic self-word beginning with "to-" and ending in "-an", forming a word that means "state" or the word "thing". The basic word "self" makes the word independence inseparable from the translation of the word "self" itself, which in the concept of Carl Rogers mentions in his concept the term self because the self is the essence of independence (Ali \& Asrori, 2008: 109). "Independence" is the original word for independence according to a psychological dictionary and is defined as "a condition where people do not hang themselves from others when making decisions and accompanied by an attitude of self-confidence (Chaplin, 2011: 343).

Bruner in (Dahar, 2006: 77) in learning raises 3 principles that may develop in elementary schools, namely: To encourage students, in this case, students of SD Muhammadiyah 8 Surabaya in grades 4,5 , and 6 to learn, learning has a connection with experiences with environmental contexts. So that students can learn from things that 
are easy to more difficult things, learning must be structured. And so that students in this case students of SD Muhammadiyah 8 Surabaya grades 4,5 and 6 can explore on their own in the construction of their knowledge (independently) then learning must be arranged in such away.

In the description of the theory and application above, the author intends to present a qualitative analysis regarding the independent character of elementary school children during the Covid-19 pandemic conditions. The focus of the research is information related to the independent character that appears in students, in this case, students of SD Muhammadiyah 8 Surabaya grades 4,5 and 6.

The objectives of this study are as follows: 1 . To determine the development of independent character values in students, in this case, students of SD Muhammadiyah 8 Surabaya grades 4,5 and 6 SD Muhammadiyah 8 Surabaya who appeared during the Covid-19 pandemic; 2. To find out the problems of developing the independent character of students, in this case, students of SD Muhammadiyah 8 Surabaya, grades 4.5 and 6 SD Muhammadiyah 8 Surabaya which was not achieved during the COVID-19 pandemic.

Silalahi (2015) states that character education in the family is related to student interest, in this case, it shows that the better character education in the family the higher the child's interest in learning in the following lessons. At this point, this study intends to add information that the independent character values of students of SD Muhammadiyah 8 Surabaya who appear in the Covid-19 pandemic will be connected to the family character. Meanwhile, according to Husna (2017) states that independent character education can be seen from the aspects of self-development, integration in subjects, and school culture. The aspect of self-development is seen from routine activities, spontaneous activities, modeling, and conditioning.

\section{Method}

In this study, a qualitative research approach was used with data in the form of words. Bogdan and Taylor (Moleong, 2012: 4) describe that qualitative research will produce descriptive data in the form of words that are written or spoken orally from people and subjects (actors) and can be observed. Meanwhile, according to M. Djunaidi Ghony and Fauzan Almanshur (2012: 25) explain that research whose findings are not 
58 An Analysis of Independent Character of Primary School Students in Learning From Home During The Covid-19 Pandemic (A Case Study at SD Muhammadiyah 8 Surabaya)

Umar Haiq, Badruli Martati, Fajar Setiawan

obtained by using statistical procedures and quantitative methods is called qualitative research.

The researcher intends to find out the values of independent character in students, in this case, students of SD Muhammadiyah 8 Surabaya grades 4.5 and 6 who appeared in the Covid-19 pandemic. Data collection was carried out in natural conditions during the Covid-19 pandemic (natural setting), the primary data source was in the form of a questionnaire. Data collection techniques were carried out by indirect observation through online questionnaires, interviews with homeroom teachers and subjects, and documentation of student learning outcomes in the form of portfolios, responses, and feedback from students of SD Muhammadiyah 8 Surabaya grades 4, 5, and 6. Data analysis was carried out using data reduction, data display, and data verification. As a form of data validity reinforcement, in filling out the questionnaire students selected were grade 4, 5, and 6 students who in terms of their level of understanding in filling out the questionnaire were able and strengthened by parental assistance, documents, and portfolios of children's assignments and also the results of interviews with teachers and teacher.

\section{Result and Discussion}

The discussion of this study shows the independent character obtained through a questionnaire where students, in this case, students of SD Muhammadiyah 8 Surabaya, grades 4,5 , and 6 , show the behavior of not depending on others, using their thoughts, energy, and personal time in realizing dreams, hopes. , and ideals. The values observed are The value of hard work where students, in this case, students of SD Muhammadiyah 8 Surabaya in grades 4, 5, and 6 show serious behavior and efforts in overcoming learning barriers, assignments, and completing them as well as possible. The observed behavior is that students carry out tasks without the help of others. An indicator is the completion of a task without help from others and being able to assist other siblings (category of culture / M); students can complete tasks without help from others (developing category / B); completion of tasks with a little help from others (category starting to develop / MBK). Students ask other people to complete tasks (category requires guidance / MB). Examples of activities are students, in this case, 
students of SD Muhammadiyah 8 Surabaya grades 4,5 , and 6 doing the task of sweeping and washing dishes after eating.

The value of curiosity where students, in this case, students of SD Muhammadiyah 8 Surabaya grades 4,5 , and 6 show the behavior of always trying to know more deeply and broadly about what is learned, seen, and heard. What is observed is the behavior of students in seeking information related to subject matter through various sources or asking questions. As an indicator, students can find information from various sources related to the subject matter and invite siblings like themselves (cultured category / $M$ ), take the initiative to ask questions or seek information from sources related to the subject matter (developing category / B), only occasionally need support / encouraging people to ask questions or seek information from sources related to the subject matter (category starting to develop / MBK), often need support/encouragement from others in questioning or seeking information from sources related to the subject matter (category needs guidance / MB ). Examples of activities are students, in this case, students of SD Muhammadiyah 8 Surabaya grades 4,5 and 6 looking for information by reading if there are questions from the teacher.

The value of responsibility in the learning awareness of students. Observation of their behavior is the learning habits of students, in this case, students of SD Muhammadiyah 8 Surabaya in grades 4,5 and 6 . The indicator is that students can become friends with other siblings in learning (cultural / $M$ category), without having to be reminded by others in terms of learning (developing category / B), still, need to be reminded by others in terms of learning but only occasionally (category starting to develop / MB), always need to be reminded by others in terms of learning (category requires guidance ( $\mathrm{MB}$ ). Examples of activities are students, in this case, students of SD Muhammadiyah 8 Surabaya grades 4,5 and 6, study regularly according to the daily learning schedule that has been made by students, in this case, students of SD Muhammadiyah 8 Surabaya grades 4,5 and 6 .

The value of responsibility in the learning awareness of students, in this case, students of SD Muhammadiyah 8 Surabaya, grades 4,5 , and 6 . The observed behavior is the attention of the students in the lesson. The indicator is that in all learning/work at home students are actively involved (cultural category / M), students pay attention to all the lessons/work given (developing category / B), students pay attention only to the 
60 An Analysis of Independent Character of Primary School Students in Learning From Home During The Covid-19 Pandemic (A Case Study at SD Muhammadiyah 8 Surabaya)

Umar Haiq, Badruli Martati, Fajar Setiawan

lessons/work they like ( developing category / MB), paying less attention to the lessons/work provided (category requires guidance / MB). Examples of activities are students, in this case, students of SD Muhammadiyah 8 Surabaya grades 4,5 and 6 have a sweeping schedule and carry out their duties properly.

Values do not depend on themselves, where students in this case students of SD Muhammadiyah 8 Surabaya grades 4,5 and 6 do not depend on others. The observed behavior is that students have confidence in doing homework. The indicator is the growth of enthusiasm in doing individual tasks at home and being able to be a motivator (leader) for others (Cultured category / $M$ ), students can do individual and group assignments at home (developing category / B), students do assignments Individuals and groups at home, although for individual assignments they still need assistance/guidance (category starting to develop / MB), refusals arise when asked to do individual tasks at home but are willing to do group assignments (category requires guidance / MB). Examples of activities are students, in this case, students of SD Muhammadiyah 8 Surabaya grades 4,5 and 6 want to tidy up their toys after playing.

According to Piaget in (Dimyati and Mugjiono 2006: 14) elementary school students in terms of intellectual development, some stages are passed, namely: the age stage 0-2 years (motor sensory), the age stage 2-7 years (pre-operational), the age stage 7-11 years (concrete operational), and 11-over age stage (formal operation). Based on the stages of Piaget's development, students, in this case, students of SD Muhammadiyah 8 Surabaya in grades 4.5 and 6 of primary school age studied, were in a concrete operational stage. where the child's thinking ability will be maximized if the object that is the source of his thinking is a real or concrete object. Psychologically, the characteristics of students, in this case, students of SD Muhammadiyah 8 Surabaya in grades 4,5 and 6 of elementary school age, are: (1) consider learning to be playing, (2) happy to be active, (3) Happy to work in groups, 4) high curiosity, and (5) like interesting things.

From the results of questionnaires to students, in this case, students of SD Muhammadiyah 8 Surabaya grades 4,5 and 6 who are presented online via google form with parental assistance, the achievement of independent character is obtained as follows: The value of students' hard work in completing tasks from parents without the help of others with the cultural category $(\mathrm{M})$ is $47.5 \%$; developing category (B) was 
$33.30 \%$; the developing category (MBK) was 19\%; the category requiring guidance (MB) was $0.2 \%$. Here 47 out of 99 students have a spirit of independence and can pass on their independent character to others and can pass on their positive character to others during the Covid-19 pandemic.

The value of curiosity of students in terms of finding information related to the subject matter through various sources or asking questions, the cultural category (M) was $12.10 \%$; developing category (B) is $47.50 \%$; the category started to develop (MBK) was $35.40 \%$; the category requiring guidance (MB) is $5 \%$. As many as 47 out of 99 children showed their curiosity character began to develop. Where students are able and willing to ask questions to find information from various sources related to subjects on their initiative during the Covid-19 pandemic.

The value of the students' responsibility in terms of learning awareness as shown by attention to the cultural category (M) is $29.30 \%$; developing category (B) is 46.50\%; starting to develop (MBK) was $19.20 \%$; require guidance (MB) is $5 \%$. As many as 47 students out of 99 students are in the category of students who have independent behavior by paying attention to all lessons and jobs given by parents during the Covid-19 pandemic. The value of responsibility of students in terms of learning awareness which is shown through the learning habits of the cultured category $(M)$ is $9.00 \%$; developing category (B) is $26.30 \%$; the category started to develop (MBK) was $48.50 \%$; require guidance $(\mathrm{MB})$ is $16.20 \%$. In the indicator of student learning habits, it shows that 48 out of 99 children need to be reminded occasionally by parents and teachers to study at home during the Covid-19 pandemic. The high percentage of this indicator shows the problems that arise in the growth of independent character when studying at home in the Covid-19 pandemic, where students still need to be reminded and motivated occasionally in learning.

The value of self-reliance that students have with self-confidence concerning doing homework in the cultural category $(\mathrm{M})$ is $17.2 \%$; the developing category $(\mathrm{B})$ was $34.3 \%$; the category started to develop (MBK) was $48.5 \%$; category requiring guidance $(\mathrm{MB})$ is $0 \%$. In observing the level of self-confidence of students in doing assignments during the pandemic, it showed that 48 out of 99 children were willing to do individual and group assignments at home even though individual assignments still needed help and guidance. 
62 An Analysis of Independent Character of Primary School Students in Learning From Home During The Covid-19 Pandemic (A Case Study at SD Muhammadiyah 8 Surabaya)

Umar Haiq, Badruli Martati, Fajar Setiawan

With the achievement of the greatest percentage of each aspect according to the indicators are as follows: The value of hard work is the largest percentage of students can complete tasks from parents without help from others and provide assistance to other siblings (cultural category / M) with a value of $47.50 \%$. The highest percentage value of curiosity was that students were willing and able to take their initiative in terms of asking questions or seeking information from various sources related to the subject matter (developing category / B) with a value of $47.50 \%$. The largest percentage value of responsibility is that students still need to be reminded by others to learn even though only occasionally (developing category / B) with a value of $46.50 \%$. The largest percentage of the value of responsibility is that students have paid attention to all lessons/jobs given by parents (starting to develop / MBK) with a value of $48.50 \%$. The largest percentage of non-dependence scores is that students are willing to do individual and group assignments at home even though individual assignments still need assistance/guidance (starting to develop / MBK) with a value of $48.5 \%$.

The results of interviews with teachers regarding the responses and reciprocity of students learning from home in the Covid-19 pandemic showed that the average grades 4,5 , and 6 were a direct response of $90 \%$, and a delayed response of $10 \%$. For the percentage of assignment, the collection is $80 \%$ direct task response and $20 \%$ delayed task response. Whereas in the form of providing material, assignments, and student assessment results in the Covid-19 pandemic by teachers, the cognitive aspects were $40 \%$, the affective aspects were $40 \%$ and the psychomotor aspects were $20 \%$.

The relationship with the analysis of the independent character of students, teachers in grades 4, 5, and 6 of SD Muhammadiyah 8 Surabaya represent the achievement of the greatest independent character values from each aspect according to the indicators as follows: The value of hard work is the largest percentage of students can complete the task from teachers without help from other people as well as assisting other siblings (cultural category / M) with a value of $47.5 \%$. The highest percentage value of curiosity was that students were willing and able to take their initiative in terms of asking questions or seeking information from various sources related to the subject matter (developing category / B) with a value of $47.50 \%$. The largest percentage value of responsibility is that students still need to be reminded by others to learn even though only occasionally (developing category / B) with a value of $46.50 \%$. The largest 
percentage of the value of responsibility is that students have paid attention to all the lessons/work given by the teacher (starting to develop / MBK) with a value of $48.50 \%$. The largest percentage of non-dependence scores is that students are willing to do individual and group assignments at home even though individual assignments still need assistance/guidance (starting to develop / MBK) with a value of $48.5 \%$.

The growth of the independent character of grades 4, 5, and $6 \mathrm{SD}$ Muhammadiyah 8 Surabaya students has been well developed. This is influenced by the inculcation of both family and school character through self-development programs, integration in subjects, and school culture seen from routine activities, spontaneous activities, modeling, and conditioning during school.

The documentation of learning from home obtained by the teacher is photos of activities, photos of structured assignments, learning videos, voice notes, chat lists, and others. As consideration for the validity of the data obtained, where the quality of the independent character of students learning from the home of SD Muhammadiyah 8 Surabaya during the Covid-19 pandemic shows that the achievement of the above indicators is the condition of students who have bad habits that have been implanted from an early age both at school and at home before the pandemic COVID-19, as well as family environmental conditions that require children to have an independent character because most of the students' parents are workers. The questionnaire distributed refers to the rubric of independent character assessment of the education assessment center of the Ministry of Education and Culture's research and development agency.

\section{Conclusion}

From the results of the data above, it can be seen that the values of independent character in students, in this case, students of SD Muhammadiyah 8 Surabaya grades 4,5 and 6 in learning from home during the Covid-19 pandemic, have developed even though occasionally assistance is needed. The independent character of students grows because it is influenced by the character of the family and the selfdevelopment that has been carried out by the school through integration with all aspects of the school.

As the author's suggestion is the need for improvement in student self-confidence by continuing to provide the motivation that is integrated with all learning programs 
64 An Analysis of Independent Character of Primary School Students in Learning From Home During The Covid-19 Pandemic (A Case Study at SD Muhammadiyah 8 Surabaya)

Umar Haiq, Badruli Martati, Fajar Setiawan

from home during the Covid-19 pandemic by teachers. Parents and students can be invited to be involved in activities that can build student independence by creating an atmosphere that provides opportunities for students to learn independently. Providing opportunities and trust by all parties to students when working on assignments and not only giving assessments on the results, but it is also necessary that an assessment in the process will build students' confidence in carrying out assignments.

\section{Reference:}

Ali, Mohammad and Mohammad Asrori. 2008. Psikologi Remaja Perkembangan Peserta didik. Jakarta: PT.Bumi Aksara.

Bogdan, Robert and Taylor. 1992, "Pengantar Metode Penelitian Kualitatif, Terjemahan oleh Arief Rurchan, Surabaya : Usaha Nasional.

Chaplin, J.P. 2001. Kamus Lengkap Psikologi (Terjemahan Kartini Kartono). Jakarta: Raja Graindo Perkasa.

Dahar, R.W. 2006. Teori-teori Belajar dan Pembelajaran. Bandung: Erlangga.

Dimyati dan Mudjiono. 2006. Belajar dan Pembelajaran. Jakarta: PT Rineka Cipta.

Ghony M.Djunaidi dan Fauzan Almanshur . 2012 "Metodologi Penelitian Kualitatif". Jogjakarta: Ar-Ruzz Media.

Moleong, L. J. 2010. Metodologi Penelitian Kualitatif, Bandung: Remaja Rosdakarya.

Permendikbud . 2020. Peraturan Menteri Pendidikan dan Budaya no. 4 Tahun 2020 poin 2 tentang pelaksanaan kebijakan pendidikan dalam masa darurat penyebaran corona virus disease (Covid-19).

Pusat Penilaian Pendidikan.2018. Rubrik Penilaian Karakter. Jakarta: Kementrian Pendidikan dan Kebudayaan

Sugiyono. 2015. Metode Penelitian Kombinasi (Mix Methods). Bandung: Alfabeta.

Husna, Liala (2017). Pendidikan Karakter Mandiri Pada Siswa Kelas 4 Sd Unggulan Aisyiyah Bantul 964 Jurnal Pendidikan Guru Sekolah Dasar Edisi 10 Tahun ke6 9215-20704-1-SM 
Silalahi ,Wesly (2015). Hubungan Pendidikan Karakter Dalam Keluarga Dengan Minat Belajar Siswa Kelas 4 Negeri Limau Manis, Handayani Journal PGSD Fakultas Ilmu Pendidikan Universitas Medan Vol 4, No 2.

(C) 2020 by the authors. Submitted for possible open access publication under the terms and conditions of the Creative Commons Attribution ShareAlike (CC BY SA) license (https://creativecommons.org/licenses/by-sa/4.0/). 